AperTO - Archivio Istituzionale Open Access dell'Università di Torino

\title{
Prediction of the dry-milling performance of maize hybrids through hardness-associated properties
}

\section{This is the author's manuscript}

Original Citation:

Availability:

This version is available http://hdl.handle.net/2318/129269

since 2016-07-04T19:41:34Z

Published version:

DOI:10.1002/jsfa.5897

Terms of use:

Open Access

Anyone can freely access the full text of works made available as "Open Access". Works made available under a Creative Commons license can be used according to the terms and conditions of said license. Use of all other works requires consent of the right holder (author or publisher) if not exempted from copyright protection by the applicable law. 


\section{(3) \\ UNIVERSITÀ DEGLI STUDI DI TORINO}

This is an author version of the contribution published on:

Questa è la versione dell'autore dell'opera: Journal of the Science and Food Agriculture, , 93 (6) 13561364, 2013, DOI: 10.1002/jsfa.5897 The definitive version is available at: La versione definitiva è disponibile alla URL: http://onlinelibrary.wiley.com/doi/10.1002/jsfa.5897/full 
Title: Prediction of the dry-milling performance of maize hybrids through hardness-associated properties.

Running title: Dry-milling performance and maize hardness tests

Massimo Blandino*, Dario Sacco, Amedeo Reyneri.

Department of Agriculture, Forestry and Land Management, University of Turin, via Leonardo da Vinci 44, 10095 Grugliasco (TO), Italy

* Corresponding author: Tel: +39-011-6708895; fax +39-011-6708798.

E-mail address: massimo.blandino@unito.it 


\section{Abstract}

2 BACKGROUND: The hardness of kernels determines the dry-milling processing 3 performance of maize hybrids. The identification of the best maize hybrids for 4 the dry-milling process requires a limited number of simple, practical and 5 reliable tests that are able to predict the potential grit yield.

6 RESULTS: 119 samples from different genetic and environmental backgrounds,

7 collected over 3 years, have been analyzed for the coarse-to-fine ratio $(C / F)$,

8 floating test $(\mathrm{FLT})$, protein content $(\mathrm{PC})$, kernel sphericity $(\mathrm{S})$, total milling 9 energy (TME) and test weight (TW). The total grit yield (TGY) of each sample has been obtained through a micromilling procedure, based on the manual separation of kernel endosperm, followed by grinding and sieving under standard operation conditions, The TGY has been used to establish the capability of the tests to predict the dry-milling aptitude. Single and multiple linear regression analysis were performed to establish the prediction equations of the TGY values, using $\mathrm{C} / \mathrm{F}, \mathrm{FLT}, \mathrm{PC}, \mathrm{S}, \mathrm{TME}$ and TW as independent variables. The analysis were performed on 3 data set, clustered year by year of the sample collection and analysis, and the resulting average coefficients of determination $\left(\mathrm{R}^{2}\right)$ were compared through an analysis of variance. $\mathrm{C} / \mathrm{F}, \mathrm{FLT}$ and TME and, to a lesser extent TW, appeared to be easy-to-use independent descriptors of maize dry-milling. An improved model prediction ability was observed when different combinations of a few physical and chemical properties were used as input variables. However, the models in which 3 or more variables were used did not lead to any significant improvement in TGY prediction compared to the smaller models. 
25 CONCLUSION: This study contributes towards establishing the best predictor of

26 maize kernel aptitude to dry-milling processes. Of all considered data sets, a

27 milling evaluation factors (C/F or TME), associated with kernel density,

28 measured by means of the FLT, showed the best predictive ability for dry-milled

29 product yields.

30

31 Keywords: maize quality properties, dry-milling, hardness methods. 


\section{Introduction}

Maize kernel hardness is an important grain quality attribute that plays a key role in the processing of cereal grains and in the end-use quality of cereal grain products ${ }^{1}$. In the dry-milling process, maize is run through a series of mills with various roller gaps, and different products are produced on the basis of the various particle sizes ${ }^{2}$. The most common products obtained in the maize milling industry are prime or large grits, which are characterized by a higher particle size than $700 \mu \mathrm{m}$, and are considered desirable by dry-millers because of their high economic value. The maize used for dry-milling should be hard, with large kernels, and with pericarps and germs that are easy to remove during the process ${ }^{3,4}$. Softer kernels can reduce the efficiency of the extraction yield of this process ${ }^{5,6}$.

The physical and biochemical aspects of maize hardness has been described in numerous publications, and several different tests have been suggested to determine the hardness of maize ${ }^{7}$. These include methods based on the physical characteristics, such as kernel size and shape, weight and density, resistance to grinding or to abrasion, quantification of coarse and fine material after grinding and sieving and ground material viscosity or on the biochemical characteristics, including protein, starch, oil and ash content and composition. Among the indirect measurements, NIR has been used in both reflectance and transmission modes to estimate maize hardness ${ }^{8}$. Most of these methods provide variable information on the range of hardness of a maize sample and the correlations between quality measurements and end-use processing performance reported in scientific literature varies to a great extent ${ }^{9,10,11}$. Moreover, in spite of the importance of hardness in dry-milling and the number 
of studies that have been published on this subject, there is still no generally accepted standard for the evaluation of the physical properties of maize kernels associated with processing performance ${ }^{12}$. Lee et al. ${ }^{11}$ suggest that conducting only a few test emphasizes the risk of misclassification of maize hybrids. Therefore, grouping maize samples, and taking into account more hardnessassociated physical and chemical properties simultaneously, could be a safer and more reliable way of determining the overall hardness of maize kernel or their aptitude to transformation. On the other hand, the evaluation of maize hybrids for the dry-milling performance requires a limited number of simple, practical and reliable tests, which could help breeders, producers and processors predict their potential grit yield.

A previous study ${ }^{13}$, pointed out which quality kernel factors and hardness tests, among the most commonly used ones, are more closely correlated to grit yield, in order to improve the description of maize hardness measurement in relation to this specific end-use value. Among the compared hardness-associated properties, quantification of coarse and fine material after grinding (C/F), kernel density by means of the floating test (FLT) and resistance to grinding (TME) resulted to be good descriptors of maize milling ability. Among the more simple and less time-consuming tests, test weight (TW), protein content (PC) and kernel sphericity (S) showed a good correlation with grit yield.

The aim of the present study was to analyze the relationship existing between some of the most simple and easily applied hardness tests and the grit yield, in order to compare the predictability of different single and multiple linear models and develop a standard set of criteria to help maize producers, breeders and processors identify the most suitable grains for dry-milling. 
Experimental

\section{$\underline{\text { Maize grain samples }}$}

During the years 2007, 2008 and 2009, overall 36 commercial and precommercial grain maize hybrids were grown in strip-test fields in North Italy.

The selected hybrids were considered representative of maize yellow hybrids commonly grown in North Italy. The 36 different maize hybrids, which were tested for several quality kernel factors and hardness tests, are listed in Tables 1. The plot size was $100 \mathrm{~m}$ by 8 rows, and the row spacing was 0.75 for each year and in each site. The experimental fields were cultivated adopting the normal agronomic techniques of each site. The number of maize grain samples collected each year was 41, 36 and 42 in 2007, 2008 and 2009, respectively. The number of different maize hybrids and the number of sites in which the samples were collected each year is reported in Table 2.

At the harvest, one hundred ears were collected by hand for each hybrid at the end of maturity (moisture content of the grains between $20-26 \%$ ) and shelled using an electric sheller, with minimum kernel breakage. The kernels were mixed thoroughly to obtain a random distribution of the kernels and a $3 \mathrm{~kg}$ sample was slowly air-dried at low-temperature (40 ${ }^{\circ} \mathrm{C}$ for $48 \mathrm{~h}$ ) to a $\approx 13 \%$ moisture content and stored in a cool room at $5^{\circ} \mathrm{C}$ and $30 \% \mathrm{RH}$ until required. After storage, the kernels, equilibrated with the air in the cool room, resulted in a mean moisture content of $\approx 10 \%$ when tested. All the samples were equilibrated to room temperature $\left(24 \pm 1^{\circ} \mathrm{C}\right)$ in paper bags for $48 \mathrm{~h}$ before the tests. 
106 The harvest and drying procedure was conducted to avoid as low as possible the kernel stress cracking, in order to reduce the possible interaction between the internal cracks, the grits yield and the hardness measurements ${ }^{7}$.

\section{Measurement of the dry-milling yield of the grits and quality factors}

The determination of dry-milling yield of the grits and all the other tests were only performed on typical, flat-shaped, whole kernels from the middle part of the ear, free from defects, which were selected visually from each sample.

Micromilling procedure (TGY). A micromilling procedure was used according to Yuan and Flores ${ }^{14}$ to process the maize grain sample and provide an index of the efficiency of the quality tests for dry-milling processing. Twenty intact, whole kernels were soaked in distilled water for $1 \mathrm{~h}$ at room temperature $\left(24 \pm 1^{\circ} \mathrm{C}\right)$ and the bran pericarp and germ were removed manually using a scalpel. The procedure was always performed by the same trained researcher to ensure a standardized determination and avoid subjective determination. The obtained endosperms were conditioned in a oven at $40^{\circ} \mathrm{C}$ for $48 \mathrm{~h}$, and were then ground and sieved using the same procedure as in the particle size index test. The total grit yield (TGY), corresponding to a percentage of the fraction from 2.000 to 700 $\mu \mathrm{m}$, was chosen to represent the main products obtained in the conventional dry-milling industry ${ }^{4}$. This procedure was conducted 3 times for each maize sample.

The TGY was expressed as a percentage of the total dry-milled fractions $\left(\mathrm{g} \mathrm{kg}^{-1}\right)$. Since this procedure achieved a good separation of the bran, germ and endosperm ${ }^{14}$, and the grounding operations were conducted under standard conditions for all the compared maize samples, micromilling can be considered 
132 to provide a good index of dry-milling performances. To confirm its representativeness, the TGY, obtained with the micromilling procedure, has been compared to the grits yield achieved in an industrial dry mill, considering only maize lots consisting of a single hybrid $\left(R^{2}=0.797, P=0.001, n=13\right)$.

Coarse-to-fine material ratio (Particle size index - CF). A 20-g kernel sample was ground using a Culatti micro hammer mill (Labtech Essa ${ }^{\circledR}$, Australia) fitted with a 2-mm aperture particle screen and was sieved into two fractions using a Ro-Tap Testing Sieve Shaker (W.S. Tyler Co., Cleveland OH) with 8-in diameter brass sieves. Sieve meshes of 500 and $700 \mu \mathrm{m}$ were chosen to represent the most common product obtained in the milling industry: prime or large grits $(700-2000 \mu \mathrm{m})$ and fine meal $(<500 \mu \mathrm{m})$. The coarse material (C) consisted of fractions of 700 to $2000 \mu \mathrm{m}$, while the fine material $(\mathrm{F})$ was made up of fractions below $500 \mu \mathrm{m}^{4,15}$. The intermediate fraction was small and was not considered. CF denotes the ratio of fractions $\mathrm{C}$ and $\mathrm{F}$, which were determined by weight after grinding in the tester. This parameter was determinated 3 times for each maize sample.

Floating Test (FLT). This test was used to assess the density of the maize grain; the number of floating kernels (floaters) was recorded in a variable density solution. The method, carried out in a laboratory fume hood is a modification of that proposed by Wichser ${ }^{16} .100 \mathrm{ml}$ of tetrachloroethylene (density $1.62 \mathrm{~g} \mathrm{ml}^{-1}$ ) and $40 \mathrm{ml}$ of petroleum ether (density $0.653 \mathrm{~g} \mathrm{ml}^{-1}$ ) were added to an Erlenmeyer flask; the obtained solution density was $1.34 \mathrm{~g} \mathrm{ml}^{-1}$. A 50 kernel sample was put into an Erlenmeyer flask. $5 \mathrm{ml}$ of petroleum ether was gradually added to the solution and the density of the solution was decreased 
until there were no kernels left floating. The number of kernels floating for each addition of petroleum ether to the solution was recorded and a precipitation curve was obtained. The floating test (FLT) measures the area underneath the precipitation curve and this parameter is adversely correlated to the density of the kernels. This parameter was determinated 3 times for each maize sample.

Protein content (PC). A grab sample of approximately $300 \mathrm{~g}$ of maize was ground to a fine flour using a Foss Tecator Cyclotec 1093 sample mill, fitted with a 1-mm screen. The Protein $(P C)$ content was estimated by near-infrared reflectance spectroscopy, using a NIRSystems 6500 monochromator instrument (Foss-NIRSystems, Silver Spring, MD, USA). The protein content was adjusted to a $10 \%$ moisture content, using the NIR-predicted moisture content of the ground grain.

Kernel Dimensions and Sphericity (S). The spatial dimensions of 50 kernels of each hybrid were calculated by measuring the average length (L), width (W) and depth (D) of the whole kernels using a precise $0.1 \mathrm{~mm}$ gauge. These data were used to calculate the sphericity $(S)$ using the following formula ${ }^{17}$ :

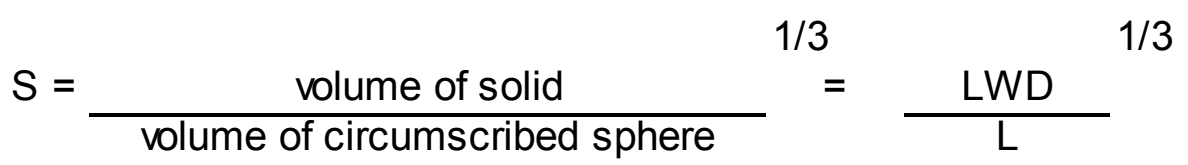

The sphericity values range from 0 (no three-dimensional object) to 1 (perfect sphere). The closer the sphericity is to unity, the more spherical the kernel; conversely, the lower the sphericity, the flatter the kernel. 
181 Total milling energy (TME). This test was based on the method described by 182 Stenvert ${ }^{18}$ and Pomeranz et al. ${ }^{17}$. A 20-g sample of kernel was ground using a 183 Culatti micro hammer mill (Labtech Essa ${ }^{\circledR}$, Australia) fitted with a 2-mm aperture particle screen at a speed of $2500 \mathrm{rpm}$ when empty. The laboratory mill was equipped with a computerized data logging system to log the instantaneous electric power consumption during the milling test, as reported by Mesters et al. ${ }^{19}$ and Li et al. ${ }^{9}$. The total milling energy (TME) necessary to completely mill a 20-g kernel sample was determined from these data. This parameter was determinated 3 times for each maize sample.

Test weight (TW). The test weight was determined 3 times for each maize sample using a Dickey-John GAC2000 grain analysis meter, according to the supplied programme. The test weight was recorded as $\mathrm{kg} \mathrm{hl}^{-1}$.

\section{Statistical analysis}

Statistical data analysis was carried out with the software package SPSS, version 16.0 (SPSS Inc., 2008). When present, replicates of the quality factor and TGY were averaged. Simple correlation coefficients were obtained for all the quality factors, relative to each another and to the TGY, keeping the data sets which refer to the 3 different years of sample collection and analysis separate.

Single and multiple linear regression analysis were performed, using the C/F, FLT, PC, S, TME and TW quality factors as the independent variables and TGY as the dependent variable. Overall, 63 regressive models, derived from the all the possible single and multiple combinations of the 6 quality factors, were 
206 compared. The analysis were performed separately for 3 data sets, clustered 207 according to the sample collection and analysis years.

208 An analysis of variance (ANOVA) was utilized to compare the coefficient of 209 determination $\left(R^{2}\right)$ of the single and multiple regressive equations, which, 210 among the compared models, resulted significant $(P<0.05)$ for all the 3 data 211 sets. The linear regressive models which did not show a significant contribution 212 for each of the single involved parameter for all of the 3 data sets, were not 213 considered. The $\mathrm{R}^{2}$ obtained from the single and multiple regression analysis on 214 the data sets of each year was used as a replication. The residual normal 215 distribution was verified using the Kolmogorov-Smirnov test, while variance 216 homogeneity was verified using the Levene test. Multiple comparison tests were 217 performed on the coefficient of determination means according to the SNK test. 


\section{Results}

220 The average, minimum and maximum values and the coefficient of variation 221 (CV) for TGY and the other analyzed parameters are shown in Table 2 for the overall 119 samples on the basis of the year of the sample collection and analysis.

The maize samples from different hybrids and sites showed great differences in their aptitude to dry-milling transformation, since the observed CV for TGY was $12 \%, 9 \%$ and $14 \%$, for the samples collected and analyzed in 2007, 2008 and 2009, respectively. Off all the compared parameters, C/F had the highest CV, and this was followed by FLT and TME.

Table 3 reports the correlation coefficients and the significances between the parameters of the analyzed maize kernels, separated according to the year of sample collection and analysis. TGY resulted to be significantly correlated to C/F, FLT, PC, S, TME, TW for all 3 data sets. The correlation was always highly significant $(P<0.01)$, with the exception of that for $S$ in the 2009 data set $(\mathrm{P}<0.05)$.

As expected, the different parameters were often significantly correlated to each other. The correlation between all the compared quality factors was significant in the 2007 data set. The correlation between S and FLT in 2008 and those between $S$ and C/F, PC, TW in 2009, were the only ones that were not significant.

Table 4 reports the $R^{2}$ and the significance of the regressive equations and parameters, derived from the different linear regressive models. The compared models were obtained from all the possible single and multiple combinations of the compared quality factors, in order to predict TGY. The reported $\mathrm{R}^{2}$ refers to 
244 the average $\mathrm{R}^{2}$ obtained from the regression analysis applied separately to samples of each data set, clustered year by year. Although the quality factors resulted to be highly correlated, they were all kept in the models in order to find the ones that showed the highest prediction of TGY.

The reported significance of the regressive equation and parameters refers to the least significant value observed between the 3 data sets. When the significance of the contribution of each parameter was higher than 0.05 , for at least one of the data sets for each linear regressive models, the reported significance value was ns (not significant).

All the single regressive models (No.s 1-6), that considered C/F, FLT, PC, S, TME and TW separately in order to predict TGY, resulted to be significant. Nine of the linear regressive models with 2 independent variables (No.s 7, 10, 11, 12, 14, 15, 16, 18 and 21) were highly significant and showed a significant contribution of both of the involved parameters. In the regressive equations which considered $\mathrm{S}$, the contribution of this parameter was never significant, with the exception of model No. 16 (PC and S). Moreover, the PC parameter was not significant when it was included in a 2 independent variable regression with $\mathrm{C} / \mathrm{F}$ (No. 8) or TME (No. 17). Among the linear regressive equations that considered 3 independent variables, only 2 (No.s 33 and 34) showed a significant contribution of all the involved parameters. The contribution of C/F was always significant in the 3 independent variable regression; furthermore, when this parameter was included in the model, the addition of at least one of the others to the model was not significant.

Multivariate regressions with 4,5 or all of the 6 included parameters did not show any significant or constant contribution of the variables to the model for the 3 data sets. 
270 Figure 1 reports the ANOVA results on the $R^{2}$ values of the linear regressive model which, among the compared models, resulted to be significant $(P<0.05)$ for all of the 3 data sets. The model that included C/F and FLT as independent variables (No. 7) showed the highest average $R^{2}$ value (0.856), and this was followed by with the FLT, PC and TME (No. 33), FLT and TME (No. 14), FLT, PC and TW (No. 34), C/F and TME (No. 10) models. The regressive equations of these models, which result in the highest average $R^{2}$ value, have been calculated on the overall dataset of 119 samples and reported in Table 5.

Of all the quality factors that were compared and considering their use in single regressive models, C/F, FLT and TME resulted to be the best descriptor of maize dry-milling ability and no significantly differences were observed between these tests. The $R^{2}$ values were significantly higher for these parameters than those obtained with the other quality factors. The single regression $R^{2}$ that considered TW was significantly higher than that with PC. On the other hand, the regressive equation with $S$ as the independent variable had the lowest average $R^{2}$ value $(0.196)$.

The addition of another independent variable to a linear regressive equation often, but not always, led to a significant increase in the resulting $R^{2}$ value. For the single linear models which considered C/F (No. 1), the addition of TME and TW (models No. 10 and 11) did not lead to any significant increase in the $\mathrm{P}$ value, while a significant increase was observed in the coefficient of determination for the addition of FLT parameter to C/F (No. 7). Moreover, this model $(C / F$ and $F L T)$ had a significantly higher average $R^{2}$ value than models No. 1 and 2, which considered the C/F and FLT parameters separately. A significant advantage, in term of $\mathrm{R}^{2}$ value, was obtained by combining FLT and TME (No. 14), TME and TW (No. 21), FLT and PC (No. 12), FLT and TW (No. 
296 15), PC and TW (No. 18), and PC and $S$ (No. 16) compared to the 297 corresponding single regressions.

298 The $\mathrm{R}^{2}$ value of the models which considered 3 quality factors, FLT, PC and 299 TME (No. 33) and FLT, PC and TW (No. 34), was not significantly higher than 300 those which included 2 of the previous reported parameters (models No.s 12, 30114 and 15), with the exception of No. 18 (PC and TW).

302 


\section{Discussion}

305 The data collected in the 3 different data sets on commercial maize hybrid samples, confirm how the dry-milled product yield is closely connected to the different compositional and physical kernel properties.

Milling evaluation factors, such as C/F and TME, or kernel density, measured by means of the FLT, has been confirmed to be good predictors of dry-milled product yield. These properties are widely accepted as parameters that can be used to establish maize kernel hardness and evaluate dry-milling ${ }^{5,6,15,21}$. In the present study, these parameters, when considered alone, always explained more than $70 \%$ of the variability of the TGY. Moreover, since no significant differences were observed between $\mathrm{C} / \mathrm{F}, \mathrm{FLT}$ and TME, these results corroborate that there is no single physical test, among the ones specifically identified to describe maize kernel hardness, that is more able to provide a better dry-milling performance than another ${ }^{7}$. methods used to measure hardness to predict the dry-milling performance is a grinding step (TME), and this is followed by a sieving step (C/F), using multiple sieve sizes. This result confirms data reported in the published literature ${ }^{7}$. Since which means more energy required to grind the kernel ${ }^{9}$, these parameters could offer an indirect, but clear, evaluation of the relative amount of hard $(\mathrm{H})$ and soft (S) fractions in the kernel.

Moreover, these parameters could easily be used as reference values for the development of near-infrared (NIR) spectroscopy calibrations, which could 
constitute an excellent and rapid tool for handlers and processors. Calibrations

329 have been developed using the coarse/fine ratio ${ }^{23}$ and Stenvert mill ${ }^{11,24}$ as reference methods. Several recent reports and an AACC method ${ }^{25}$ to measure maize hardness have used a single wavelength $(1680 \mathrm{~nm})$, which is not associated to a protein wavelength but to particle size ${ }^{7}$.

Although less closely related to the TGY compared to previous reported methods, TW, recorded by means of a grain analysis meter, and PC, estimated by NIR, also resulted to be significant predictors of dry-milled product yields in all the compared data sets s, $^{9}$.

These methods, which are less time-consuming than the previous one and the currently used procedures, have proved to be practical descriptors of maize milling performance ${ }^{26}$. Although previous studies reported a variable capacity of TW to predict dry-milled yields ${ }^{9,11}$, in the present study this parameter has proved capable of explaining on average about $65 \%$ of the TGY variability of maize hybrids. Thus TW, which is widely used in the maize industry, is probably the easiest and simplest parameter to predict the dry-milling performance of maize hybrids. Moreover, although the PC comprises a lower proportion of the total kernel composition, compared to starch, it confirm that it plays a significant role in influencing kernel density and the variation in zein classes has, in particular, been linked to differences in hardness ${ }^{27}$.

On the other hand, although the collected data confirm that kernels with higher sphericity are significantly higher in flintlike characteristics than flater kernels, since the round kernels are higher in protein content and grain density than the flat kernels ${ }^{9,17}$, the relationship is constantly weak, thus this parameter is not sufficient alone to predict the $\mathrm{TGY}^{28}$. 
353 Furthermore, the present study clearly underlines how multifactorial regression analysis, which takes into account for several physical and chemical properties associated with processing performance simultaneously, often leads to a significant improvement compared to the models that are based on single variables. In the present study, the inclusion, in a linear regressive model, of 2 of the parameters more closely related to dry-milling performance (C/F, FLT and TME), always explains more than $80 \%$ of the variability of the TGY. Moreover, more than $85 \%$ of variability is on average explained with models based on $\mathrm{C} / \mathrm{F}$ and FLT factors, while this value for the two variables alone is $74.8 \%$ and $72.3 \%$, respectively.

Considering the simplest and most rapid testing procedures, such as TW and PC estimated by means of NIR, which are less closely related to TGY then previous ones, but are simpler and currently widely applied, the inclusion in a linear regressive model of both parameters explains $72.2 \%$ of the variability of the TGY, with no significant difference compared to single models that considered C/F, FLT and TME. When considered alone, TW and PC explain $64.9 \%$ and $42.8 \%$ of TGY variability, respectively. Dorsey-Redding et al. ${ }^{9}$, proposed a regression equation to predict maize kernel hardness, which was calculated using the Stenvert Hardness Test, or kernel density, based on PC, TW and oil content.

The closeness of various relationships between combined hardness measurements and dry-milling performance reported in scientific literature is very different and probably related to the genetic and environmental diversity of the considered maize samples. Mestres et al..$^{5}$, reported that TGY could be predicted at almost $60 \%$ from the ash content and sphericity or dent kernel 
percentage. On the other hand, in the study by Lee et $a l .{ }^{21}$, on samples gathered from large sample sets grown in multiple sites and over different years, the multivariate regression analysis, considering TW, PC, pycnometer density, time to grind in the Stenvert hardness test and kernel size distribution, explained only $52 \%$ of the variability in dry-milling grit yield.

The data collected in the present study have shown how a better prediction could mainly be achieved when the included parameters are based on different hardness-associated kernel properties (such as C/F and FLT, FLT and TME, TME and TW, FLT and TW, PC and TW). Similar result have been observed by Chiremba et al. ${ }^{29}$, which reported that a combination of tangential abrasive dehulling devide (TADD) and NIT milling index or TADD and TW could allow a better hardness evaluation. In their review on maize kernel testing methods, Fox and Manley ${ }^{7}$ clearly underlined how the different physical and biochemical characteristics are linked to the hardness of the whole kernel and the subsequent effect on processing. Several authors ${ }^{10,11,12,21}$ suggest that the identification of a group with similar traits, related to the end-use processing performance, could be more easily obtained using multivariate techniques which take into account the kernel hardness, associated with both the physical and chemical properties, at the same time.

The presented results, which are based on commercial maize hybrids commonly cultivated and which can be processed for dry-milling, confirm that considering more than one test is a better way of determining the overall maize kernel hardness or their aptitude to transformation. On the other hand, the combined use of variables based on a similar approach, such as C/F and TME, both of which are milling evaluator factors, only offers a slightly better prediction 
403 compared to the single models. The inclusion of four or more properties, associated with the processing performance, in a multifactorial linear regression model did not show a significant contribution of any of the inserted variables in all of the considered data sets. Furthermore, the few models that involved 3 variables and resulted significant in the considered data sets, did not improve the predictability of the model compared to the smaller ones. Several studies $^{9,10,11}$ have reported that hardness-associated properties are closely correlated to each other, a result that is consistent with our findings. This high correlation among the compared maize properties, especially if they are derived from similar tests, therefore provides a limited improvement in TGY prediction. Thus, the classification and prediction of maize samples for dry-milling could only consider a few easily achievable measurements, if they are based on different direct or indirect techniques.

In conclusion, this research offers a further contribution to help develop and guide the choice of the few relevant and easy-to-use predictive laboratory measurement techniques, in order to help the maize industry improve processing efficiency and provide quality specifications for maize growers and breeders. Among the properties associated with dry-milling performance that were compared, C/F, FLT and TME and, to a lesser extent TW, appeared to be easy-to-use independent variables to differentiate maize TGY. Improved model prediction ability was observed when different combinations of a few different physical and chemical properties were used as input variables. Furthermore, models that included 3 or more variables did not lead to any significant improvement in TGY prediction compared to the smaller models. Of all the data sets considered, the milling evaluation factors (C/F or TME) associated with kernel density, measured by means of the FLT, showed the best predictive 
429 ability for dry-milled product yields. Further investigation to identify and develop

430 better easy-to-use measurement techniques and to improve and standardize 431 the procedures are recommended.

432

433 
435 Acknowledgements

436 The funds for this research were provided through grants from the Provincia di

437 Torino, Servizio Agricoltura.

438 The authors would like to thank Mattia Ciro Mancini, Alessandro Peila and 439 Andrea Piva for their expert technical assistance. 


\section{References}

1. Shandera DL, Jackson DS and Johnson BE, Quality factor impacting processing of maize dent hybrids. Maydica 42:281-289 (1997).

2. Duensing WJ, Roskens $A B$ and Aldxandre RJ, Corn dry milling: Process, Products and application, in: Corn Chemistry and Technology, ed by White PJ and Johnson LA. AACC International, St. Paul, MN, pp. 409-447 (2003).

3. Serna-Saldivar SO, Gomez MH and Rooney LW, Food uses of regular and specialty corns and their dry-milled fraction, in: Specialty corns $2^{\text {nd }}$ edition, ed by Hallauer AR. pp. 303-333 (1991).

4. Wu YV, Corn hardness as related to yield and particle size of fractions from micro hammercutter mill. Cereal Chem 69 (3):343-347 (1992).

5. Mestres C, Louis-Alexander A, Matencio F and Lahlou A, Dry milling properties of maize. Cereal Chem 68(1):51-56 (1991).

6. Wu YV and Bergquist RR, Relation of corn grain density to yields of dry-milling products. Cereal Chem 68:542-544 (1991) .

7. Fox G, Manley M, Hardness methods for testing maize kernels. J Agric Food Chem 57:5647-5657 (2009).

8. Williams $P$, Geladi $P$, Fox G, and Manley M, Maize kernel hardness classification by near infrared (NIR) hyperspectral imaging and multivariate data analysis. Analytica Chimica Acta 653:121-130 (2009).

9. Dorsey-Redding C., Hurburgh CRJr, Johnson LA, Fox SR, Relationship among maize quality factors. Cereal Chem 68:602-605 (1991).

10. Li PX-P, Hardacre AK, Campanella OH and Kirkpatrick KJ, Determination of endosperm characteristics of 38 corn hybrids using the Stenvert hardness test. Cereal Chem $\mathbf{7 3}$ (4):466-471 (1996).

11. Lee KM, Herrman TJ, Lingenfelser $J$ and Jackson DS, Classification and prediction of maize hardness-associated properties using multivariate statistical analyses. J Cereal Sci 41:8593 (2005).

12. Lee KM, Herrman TJ, Rooney L, Jackson DS, Lingenfelser J, Rausch KD, McKinney J, liams C, Byrum L, Hurburgh CR, Johson LA and Fox SR, Corroborative study on maize 
quality, dry-milling and wet-milling properties of selected maize hybrids. J Agric Food Chem 55:10751-10763 (2007).

13. Blandino M, Mancini MC, Peila A, Rolle L, Vanara F and Reyneri A, Determination of maize kernel hardness: comparison of different laboratory tests to predict dry-milling performance. J Sci Food Agric 90:1870-1878 (2010).

14. Yuan, J, Flores, RA, Laboratory dry-milling performance of white corn: effect of physical and chemical corn characteristics. Cereal Chem 73:574-578 (1996).

15. Pomeranz Y, Czuchjowska $Z$ and Lai F, Gross composition of coarse and fine fractions of small corn samples ground on the Stenvert Hardness Tester. Cereal Chem 63:22-26 (1986).

16. Wichser, WR, The world of corn processing. Am Miller Process 89:29 (1961).

17. Pomeranz Y, Czuchjowska Z, Martin CR and Lai F, Determination of corn hardness by Stenvert Hardness Tester. Cereal Chem 62:108-110 (1985).

18. Stenvert NL, Grinding resistance, a simple measure of wheat hardness. Flour Anim Feed Milling 12: 24-26 (1974).

19. Mestres C, Matencio F, and Louis-Alexandre A, Mechanical behaviour of corn kernels: development of a laboratory friability test that can predict milling behaviour. Cereal Chem 72: 652-657 (1995).

20. SPSS Inc. 2008. SPSS Software, Release 16.0. IBM SPSS Statistics, Armonk, New York. http://www-01.ibm.com/software/analytics/spss/

21. Lee KM, Herrman TJ, Bean SR, Jackson DS and Lingenfelser J, Classification of dry-milled maize grit yield groups using quadratic discriminant analysis and decision tree algorithm. Cereal Chem 84:152-161 (2007).

22. Le Deschault de Monredon F, Devaux MF and Chaurand M, Particle size characterization of ground fraction of dent and flint maize. Sci Aliments 16 (2):117-132 (1996)

23. Robutti $\mathrm{J}$, Maize kernel hardness estimation in breeding by near-infrared transmission analysis. Cereal Chem 72:632-636 (1995).

24. Armstrong PR, Lingenfelser $\mathrm{J}$ and McKinney $\mathrm{L}$, The effect of moisture content on determing corn hardness from griding time, grinding energy and near-infrared spectroscopy. Appl Eng Agric 23:793-799 (2007).

25. American Association of Cereal Chemist. Approved Methods of the AACC, $10^{\text {th }}$ ed., AACC, St. Paul, MN, 1992. Method 36. 
1 26. Mestres C, Matencio F, Biochemical basis of kernel milling characteristics and endosperm vitreousness of maize. J Cereal Sci 24:283-290 (1996).

27. Robutti JL, Borras FS, and Eyherabide GH, Zein composition of mechanically separated coarse and fine portions of maize kernels. Cereal Chem 74:75-78 (1997).

28. Kim TH, Hampton JG, Opara LU, Hardacre AK, Mackay BR, Effects of maize grain size, shape and hardness on drying rate and the occurrence of stress cracks. J Sci Food Agric 82:1232-1239 (2002).

29. Chiremba C, Rooney LW, Taylor RN, Relationship between simple grain quality parameters for the estimation of sorghum and maize hardness in commercial hybrid cultivars. Cereal Chem 88:570-575 (2011). 
Table 1. Characteristics of the yellow maize hybrids tested for the quality kernel factors and

2 milling test, ranked for total grits yield (TGY).

\begin{tabular}{|c|c|c|c|c|c|c|c|c|c|c|c|}
\hline \multicolumn{2}{|l|}{ Hybrid and brand } & \multirow{2}{*}{$\begin{array}{c}\begin{array}{c}\text { Number } \\
\text { of sample }\end{array} \\
2\end{array}$} & \multirow{2}{*}{$\begin{array}{l}\text { Type } \\
\text { dent }\end{array}$} & \multirow{2}{*}{$\begin{array}{c}\text { CRM } \\
\text { rating }\end{array}$} & \multirow{2}{*}{$\begin{array}{c}\begin{array}{c}\text { TGY } \\
\left(g^{~ k g}{ }^{-1}\right)\end{array} \\
305\end{array}$} & \multirow{2}{*}{$\begin{array}{l}\text { C/F } \\
0.8\end{array}$} & \multirow{2}{*}{$\begin{array}{l}\text { FLT } \\
3094\end{array}$} & \multirow{2}{*}{$\begin{array}{c}\begin{array}{c}\mathrm{PC} \\
\left(\mathrm{g} \mathrm{kg}^{-1}\right)\end{array} \\
90\end{array}$} & \multirow{2}{*}{$\begin{array}{c}\mathbf{S} \\
0.62\end{array}$} & \multirow{2}{*}{$\begin{array}{c}\text { TME } \\
\text { (J) } \\
1074\end{array}$} & \multirow{2}{*}{$\begin{array}{c}\begin{array}{c}\text { TW } \\
\left(\mathbf{k g ~ h l}^{-1}\right)\end{array} \\
75.3\end{array}$} \\
\hline Syngenta NX5004 & a & & & & & & & & & & \\
\hline El6728 & $b$ & 1 & dent & 132 & 313 & 0.8 & 3505 & 100 & 0.59 & 871 & 74.5 \\
\hline Syngenta NX7234 & $a$ & 9 & dent & 125 & 322 & 0.7 & 3079 & 90 & 0.57 & 1009 & 74.7 \\
\hline DKC 4490 & $\mathrm{~b}$ & 2 & dent & 105 & 326 & 0.7 & 2749 & 86 & 0.62 & 1130 & 75.1 \\
\hline El6602 & $\mathrm{b}$ & 1 & dent & 130 & 345 & 1.0 & 3270 & 100 & 0.60 & 970 & 74.4 \\
\hline EH6716 & $\mathrm{b}$ & 1 & dent & 132 & 348 & 0.9 & 3220 & 100 & 0.57 & 1126 & 74.9 \\
\hline PR32F73 & c & 2 & dent & 130 & 360 & 0.9 & 2597 & 88 & 0.59 & 1163 & 76.8 \\
\hline DKC Tevere & $\mathrm{b}$ & 5 & dent & 125 & 362 & 0.8 & 2996 & 92 & 0.60 & 1118 & 74.3 \\
\hline DKC 6089 & $\mathrm{~b}$ & 6 & dent & 125 & 375 & 1.0 & 2710 & 96 & 0.56 & 1204 & 76.0 \\
\hline PR33W82 & c & 2 & dent & 128 & 376 & 1.0 & 2236 & 91 & 0.61 & 1305 & 79.4 \\
\hline DKC 6286 & $\mathrm{~b}$ & 3 & dent & 126 & 380 & 1.1 & 2863 & 87 & 0.59 & 1222 & 78.1 \\
\hline Syngenta NX7034 & $a$ & 5 & dent & 128 & 387 & 1.0 & 2800 & 100 & 0.63 & 1182 & 75.1 \\
\hline DKC 6677 & $\mathrm{~b}$ & 8 & dent & 128 & 395 & 1.1 & 2636 & 101 & 0.57 & 1290 & 77.8 \\
\hline El6722 & $\mathrm{b}$ & 1 & dent & 132 & 397 & 1.2 & 2830 & 101 & 0.57 & 1159 & 76.0 \\
\hline DKC 6688 & $\mathrm{~b}$ & 4 & dent & 130 & 398 & 1.1 & 2776 & 101 & 0.59 & 1205 & 77.8 \\
\hline KWS Kermess & $d$ & 5 & dent & 130 & 405 & 1.0 & 2497 & 97 & 0.58 & 1216 & 76.8 \\
\hline PR32G44 & c & 4 & dent & 130 & 408 & 1.0 & 2498 & 101 & 0.61 & 1174 & 78.8 \\
\hline EG4707 & $\mathrm{b}$ & 1 & dent & 128 & 410 & 1.0 & 2393 & 94 & 0.62 & 1212 & 74.1 \\
\hline El6207 & $\mathrm{b}$ & 1 & dent & 125 & 411 & 1.3 & 2650 & 104 & 0.61 & 1314 & 77.4 \\
\hline EH6618 & $\mathrm{b}$ & 1 & dent & 130 & 414 & 1.1 & 2885 & 107 & 0.59 & 1258 & 77.6 \\
\hline PR35T36 & C & 4 & dent & 118 & 415 & 1.0 & 2451 & 102 & 0.61 & 1223 & 79.0 \\
\hline H.C.P. DORIA & e & 1 & dent & 130 & 426 & 1.3 & 2110 & 115 & 0.59 & 1370 & 81.0 \\
\hline KWS Kuadro & $d$ & 3 & dent & 128 & 426 & 1.0 & 2459 & 97 & 0.57 & 1242 & 77.4 \\
\hline PR33A46 & c & 1 & dent & 128 & 433 & 1.2 & 2599 & 108 & 0.59 & 1319 & 78.2 \\
\hline Pioneer X1132R & $\mathrm{c}$ & 9 & dent & 132 & 434 & 1.1 & 2437 & 106 & 0.60 & 1246 & 77.8 \\
\hline Syngenta NX6413 & $a$ & 3 & dent & 126 & 439 & 1.1 & 2576 & 107 & 0.67 & 1288 & 78.8 \\
\hline PR33T56 & $c$ & 2 & dent & 127 & 440 & 1.1 & 2366 & 102 & 0.63 & 1294 & 79.1 \\
\hline DKC 6309 & $\mathrm{~b}$ & 7 & dent & 128 & 441 & 1.1 & 2501 & 104 & 0.62 & 1285 & 79.3 \\
\hline Pioneer 3235 & c & 9 & dent & 130 & 443 & 1.2 & 2175 & 108 & 0.61 & 1338 & 80.1 \\
\hline El6906 & $\mathrm{b}$ & 1 & dent & 132 & 445 & 1.4 & 2490 & 107 & 0.61 & 1358 & 79.4 \\
\hline DKC 6795 & $\mathrm{~b}$ & 1 & dent & 132 & 448 & 1.3 & 2448 & 109 & 0.64 & 1424 & 80.6 \\
\hline PR32P26 & C & 2 & dent & 130 & 455 & 1.1 & 2024 & 111 & 0.60 & 1242 & 81.4 \\
\hline Pioneer 3245 & c & 5 & dent & 130 & 463 & 1.3 & 2177 & 103 & 0.62 & 1394 & 80.9 \\
\hline H.C.P. CECINA & e & 1 & flint & 128 & 480 & 1.4 & 2123 & 105 & 0.60 & 1366 & 81.1 \\
\hline LG Belgrano & $f$ & 2 & flint & 102 & 485 & 1.4 & 1576 & 111 & 0.67 & 1595 & 82.6 \\
\hline Pioneer X1733 & c & 4 & flint & 130 & 506 & 1.4 & 1391 & 107 & 0.65 & 1533 & 82.3 \\
\hline
\end{tabular}

$4 \mathrm{CRM}=$ company ratings for relative hybrid maturity, $\mathrm{C} / \mathrm{F}=$ coarse/fine ratio, $\mathrm{FLT}=$ floating test, $\mathrm{PC}=$ protein

5 content, $\mathrm{S}=$ sphericity, $\mathrm{TME}=$ total milling energy, $\mathrm{TW}=$ test weight.

6 a Syngenta AG, Basel, Switzerland

7 ' ${ }^{\mathrm{b}}$ Monsanto Co., Creve Coeur, Missouri, U.S.

$8 \quad{ }^{\mathrm{c}}$ Pioneer Hi -Bred, Johnston, lowa, U.S

$9 \quad{ }^{d}$ KWS SAAT AG, Einbeck, Germany

$10{ }^{\mathrm{e}}$ Hybrid Corn Production, Reggio Emilia, Italy

$11{ }^{f}$ Groupe Limagrain Holding, Chappes, France 
Table 2. Experimental data of each dataset, referring to samples collected and analyzed in different years.

2

\begin{tabular}{|c|c|c|c|c|c|c|c|c|c|c|c|}
\hline Year & $\begin{array}{c}\text { Sample } \\
\text { No. }\end{array}$ & $\begin{array}{c}\text { Hybrid } \\
\text { No. }\end{array}$ & $\begin{array}{l}\text { Site } \\
\text { No. }\end{array}$ & & $\begin{array}{c}\text { TGY } \\
\left(\mathrm{g} \mathrm{kg}^{-\mathbf{1}}\right)\end{array}$ & ClF & FLT & $\begin{array}{c}P C \\
\left(g^{-1}\right)\end{array}$ & $S$ & $\begin{array}{c}\text { TME } \\
\text { (J) }\end{array}$ & $\begin{array}{c}\text { TW } \\
\left(\mathrm{kg} \mathrm{hl}^{-1}\right)\end{array}$ \\
\hline \multirow[t]{4}{*}{2007} & 41 & 21 & 6 & Mean & 406 & 1.0 & 2599 & 101 & 0.60 & 1193 & 77 \\
\hline & & & & Min & 313 & 0.6 & 2058 & 81 & 0.56 & 871 & 73 \\
\hline & & & & Max & 480 & 1.4 & 3505 & 116 & 0.67 & 1388 & 82 \\
\hline & & & & CV & 12 & 21 & 15 & 9 & 4 & 12 & 3 \\
\hline \multirow[t]{4}{*}{2008} & 36 & 20 & 3 & Mean & 433 & 1.1 & 2454 & 105 & 0.61 & 1286 & 79 \\
\hline & & & & Min & 331 & 0.7 & 1582 & 87 & 0.57 & 989 & 74 \\
\hline & & & & Max & 506 & 1.5 & 3399 & 117 & 0.68 & 1513 & 84 \\
\hline & & & & CV & 9 & 16 & 16 & 7 & 5 & 9 & 3 \\
\hline \multirow[t]{4}{*}{2009} & 42 & 17 & 6 & Mean & 385 & 1.0 & 2560 & 95 & 0.60 & 1247 & 78 \\
\hline & & & & Min & 270 & 0.7 & 1088 & 82 & 0.54 & 982 & 73 \\
\hline & & & & Max & 517 & 1.5 & 3337 & 116 & 0.67 & 1640 & 83 \\
\hline & & & & CV & 14 & 20 & 19 & 8 & 5 & 12 & 3 \\
\hline
\end{tabular}

$4 \mathrm{TGY}=$ total grit yield, $\mathrm{C} / \mathrm{F}=$ coarse/fine ratio, $\mathrm{FLT}=$ floating test, $\mathrm{PC}=$ protein content, $\mathrm{S}=$ sphericity, TME $=$ total milling energy, $\mathrm{TW}=$ test weight.

5 Min: minimum value; Max: maximum value; SD: standard deviation; CV: coefficient of variation 
1 Table. 3

2 Correlation matrix between the analysed maize kernel parameters, calculated for different 3 datasets, clustered year by year, of the collected and analysed samples.

\begin{tabular}{|c|c|c|c|c|c|c|c|}
\hline Year & Parameters & TGY & $\mathrm{C} / \mathrm{F}$ & RLT & PC & $S$ & TW \\
\hline \multirow[t]{6}{*}{2007} & $\mathrm{C} / \mathrm{F}$ & $0.866^{* *}$ & & & & & \\
\hline & FLT & $-0.855^{* *}$ & $-0.747^{\star \star}$ & & & & \\
\hline & $\mathrm{PC}$ & $0.656^{* *}$ & $0.729^{* *}$ & $-0.521^{*}$ & & & \\
\hline & s & $0.516^{* *}$ & $0.474^{* *}$ & $-0.489^{* *}$ & $0.372^{*}$ & & \\
\hline & TW & $0.818^{* *}$ & $0.836^{* *}$ & $-0.799^{* *}$ & $0.650^{* *}$ & $0.531^{* *}$ & \\
\hline & TME & $0.841^{* *}$ & $0.798^{* *}$ & $-0.747^{* *}$ & $0.729^{* *}$ & $0.474^{* *}$ & $0.776^{* *}$ \\
\hline \multirow[t]{6}{*}{2008} & $\mathrm{C} / \mathrm{F}$ & $0.857^{\text {** }}$ & & & & & \\
\hline & RLT & $-0.854^{* *}$ & $-0.699^{* *}$ & & & & \\
\hline & $\mathrm{PC}$ & $0.636^{* *}$ & $0.564^{* *}$ & $-0.526^{* *}$ & & & \\
\hline & $s$ & $0.439^{* *}$ & $0.615^{\star \star}$ & -0.267 & $0.340^{*}$ & & \\
\hline & TW & $0.814^{* *}$ & $0.733^{* *}$ & $-0.843^{* *}$ & $0.415^{*}$ & $0.456^{* *}$ & \\
\hline & TME & $0.840^{\star *}$ & $0.899^{* *}$ & $-0.724^{* *}$ & $0.467^{* *}$ & $0.514^{* *}$ & $0.681^{* *}$ \\
\hline \multirow[t]{6}{*}{2009} & $\mathrm{C} / \mathrm{F}$ & $0.872^{* *}$ & & & & & \\
\hline & RLT & $-0.841^{* *}$ & $-0.714^{* *}$ & & & & \\
\hline & $\mathrm{PC}$ & $0.670^{* *}$ & $0.668^{* *}$ & $-0.536^{* *}$ & & & \\
\hline & $S$ & $0.358^{*}$ & 0.159 & $-0.483^{* *}$ & 0.094 & & \\
\hline & $\mathrm{TW}$ & $0.784^{* *}$ & $0.802^{* *}$ & $-0.724^{* *}$ & $0.544^{* *}$ & 0.295 & \\
\hline & TME & $0.854^{* *}$ & $0.800^{* *}$ & $-0.816^{* *}$ & $0.712^{\star *}$ & $0.336^{*}$ & $0.785^{* *}$ \\
\hline
\end{tabular}

$5 \mathrm{TGY}=$ total grit yield, $\mathrm{C} / \mathrm{F}=$ coarse/fine ratio, $\mathrm{FLT}=$ floating test, $\mathrm{PC}=$ protein content, $\mathrm{S}=$ sphericity, $\mathrm{TME}=$ total $6 \quad$ milling energy, $\mathrm{TW}=$ test weight.

7 The data reported in the table are Pearson product-moment correlation coefficients. ${ }^{*}=$ correlation significant at $\mathrm{P}$ $8 \leq 0.05 ;{ }^{* *}=$ correlation significant at $\mathrm{P} \leq 0.01$. 
9 Table 4. Significance of the single and multiple linear regression models in 10 predicting TGY from different hardness tests.

\begin{tabular}{|c|c|c|c|c|c|c|c|c|c|c|}
\hline \multirow{2}{*}{ No. } & \multirow{2}{*}{ Parameters } & \multirow{2}{*}{$\begin{array}{c}\text { No. of } \\
\text { parameters }\end{array}$} & \multirow{2}{*}{$\mathrm{R}^{2}$} & \multirow{2}{*}{$\begin{array}{c}\text { Sign. } \\
\text { Regressive equation }\end{array}$} & \multicolumn{6}{|c|}{ Sign. parameters } \\
\hline & & & & & C/F & FLT & PC & $\mathbf{S}$ & TME & TW \\
\hline 1 & $\mathrm{C} / \mathrm{F}$ & 1 & 0.748 & $* \star *$ & $\star * *$ & & & & & \\
\hline 2 & FLT & 1 & 0.723 & $* \star *$ & & $\star * \star *$ & & & & \\
\hline 3 & PC & 1 & 0.428 & $\star \star \star \star ~$ & & & $\star * *$ & & & \\
\hline 4 & s & 1 & 0.196 & * & & & & * & & \\
\hline 5 & TME & 1 & 0.714 & $\star \star \star *$ & & & & & $\star * \star$ & \\
\hline 6 & TW & 1 & 0.649 & $* * *$ & & & & & & $\star \star * \star$ \\
\hline 7 & $\mathrm{C} / \mathrm{F}, \mathrm{FLT}$ & 2 & 0.856 & $* \star \star *$ & *** & $* * *$ & & & & \\
\hline 8 & $\mathrm{C} / \mathrm{F}, \mathrm{PC}$ & 2 & 0.765 & $\star \star * *$ & $* * *$ & & ns & & & \\
\hline 9 & $\mathrm{C} / \mathrm{F}, \mathrm{S}$ & 2 & 0.774 & $\star * *$ & $* * *$ & & & ns & & \\
\hline 10 & $\mathrm{C} / \mathrm{F}, \mathrm{TME}$ & 2 & 0.800 & $* \star *$ & $\star * \star *$ & & & & * & \\
\hline 11 & $\mathrm{C} / \mathrm{F}, \mathrm{TW}$ & 2 & 0.789 & $\star \star \star *$ & $* * *$ & & & & & * \\
\hline 12 & FLT, PC & 2 & 0.782 & $\star \star \star \star ~$ & & $\star \star \star *$ & * & & & \\
\hline 13 & $\mathrm{FLT}, \mathrm{S}$ & 2 & 0.744 & $\star * \star$ & & $* * *$ & & ns & & \\
\hline 14 & FLT, TME & 2 & 0.815 & $\star \star \star *$ & & $* \star \star$ & & & $\star \star \star *$ & \\
\hline 15 & FLT, TW & 2 & 0.771 & $* * *$ & & $* * *$ & & & & * \\
\hline 16 & $\mathrm{PC}, \mathrm{S}$ & 2 & 0.505 & $\star \star \star *$ & & & $\star \star \star *$ & * & & \\
\hline 17 & $\mathrm{PC}, \mathrm{TME}$ & 2 & 0.749 & $\star \star \star *$ & & & ns & & $\star \star \star *$ & \\
\hline 18 & $\mathrm{PC}, \mathrm{TW}$ & 2 & 0.722 & $\star \star \star \star ~$ & & & $*$ & & & $* * *$ \\
\hline 19 & $\mathrm{~S}, \mathrm{TME}$ & 2 & 0.726 & $* \star *$ & & & & ns & $\star \star \star \star ~$ & \\
\hline 20 & $\mathrm{~S}, \mathrm{TW}$ & 2 & 0.660 & $* * *$ & & & & ns & & *** \\
\hline 21 & TME, TW & 2 & 0.785 & $* \star *$ & & & & & 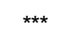 & * \\
\hline 22 & $\mathrm{C} / \mathrm{F}, \mathrm{FLT}, \mathrm{PC}$ & 3 & 0.863 & *** & $* * *$ & $* * *$ & ns & & & \\
\hline 23 & $\mathrm{C} / \mathrm{F}, \mathrm{FLT}, \mathrm{S}$ & 3 & 0.858 & $\star \star * \star$ & 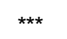 & $* * *$ & & ns & & \\
\hline 24 & $\mathrm{C} / \mathrm{F}, \mathrm{FLT}, \mathrm{TME}$ & 3 & 0.866 & $\star \star \star *$ & $\star *$ & ** & & & ns & \\
\hline 25 & C/F, FLT, TW & 3 & 0.857 & $* \star *$ & $* * *$ & $* * *$ & & & & ns \\
\hline 26 & $\mathrm{C} / \mathrm{F}, \mathrm{PC}, \mathrm{S}$ & 3 & 0.790 & $* \star *$ & $* * *$ & & ns & ns & & \\
\hline 27 & $\mathrm{C} / \mathrm{F}, \mathrm{PC}, \mathrm{TME}$ & 3 & 0.814 & $* * *$ & * & & ns & & * & \\
\hline 28 & C/F, PC, TW & 3 & 0.806 & $\star \star \star \star ~$ & $\star \star \star \star ~$ & & ns & & & * \\
\hline 29 & $\mathrm{C} / \mathrm{F}, \mathrm{S}, \mathrm{TME}$ & 3 & 0.812 & $\star \star \star *$ & $\star *$ & & & ns & * & \\
\hline 30 & $\mathrm{C} / \mathrm{F}, \mathrm{S}, \mathrm{TW}$ & 3 & 0.808 & $\star \star \star *$ & $\star \star \star *$ & & & ns & & ns \\
\hline 31 & CF, TME, TW & 3 & 0.826 & $* * *$ & * & & & & * & ns \\
\hline 32 & $\mathrm{FLT}, \mathrm{PC}, \mathrm{S}$ & 3 & 0.793 & $* \star *$ & & $* \star \star$ & * & ns & & \\
\hline 33 & FLT, PC, TME & 3 & 0.835 & $\star * *$ & & *** & * & & * & \\
\hline 34 & FLT, PC, TW & 3 & 0.811 & $\star \star \star *$ & & $\star *$ & * & & & * \\
\hline 35 & FLT, S, TME & 3 & 0.819 & $* \star *$ & & $* *$ & & ns & $* *$ & \\
\hline 36 & $\mathrm{FLT}, \mathrm{S}, \mathrm{TW}$ & 3 & 0.781 & $* * *$ & & $* * *$ & & ns & & ns \\
\hline 37 & FLT, TME, TW & 3 & 0.828 & $\star \star \star *$ & & $* *$ & & & $* *$ & ns \\
\hline 38 & $\mathrm{PC}, \mathrm{S}, \mathrm{TME}$ & 3 & 0.760 & $\star \star \star *$ & & & ns & ns & $\star *$ & \\
\hline 39 & $\mathrm{PC}, \mathrm{S}, \mathrm{TW}$ & 3 & 0.733 & $\star \star * *$ & & & $* *$ & ns & & $* * \star$ \\
\hline 40 & PC, TME, TW & 3 & 0.807 & $\star * *$ & & & ns & & $\star \star \star \star ~$ & * \\
\hline 41 & S, TME, TW & 3 & 0.789 & $* \star *$ & & & & ns & $\star \star \star *$ & * \\
\hline 42 & $\mathrm{C} / \mathrm{F}, \mathrm{FLT}, \mathrm{PC}, \mathrm{S}$ & 4 & 0.866 & $* \star *$ & $* \star \star$ & *** & ns & ns & & \\
\hline 43 & $\mathrm{C} / \mathrm{F}, \mathrm{FLT}, \mathrm{PC}, \mathrm{TME}$ & 4 & 0.872 & $* \star *$ & * & ** & ns & & $\mathrm{ns}$ & \\
\hline 44 & C/F, FLT, PC, TW & 4 & 0.865 & $\star \star \star \star ~$ & ** & ** & ns & & & ns \\
\hline 45 & $\mathrm{C} / \mathrm{F}, \mathrm{FLT}, \mathrm{S}, \mathrm{TME}$ & 4 & 0.868 & $\star \star * *$ & * & ** & & ns & ns & \\
\hline 46 & C/F, FLT, S, TW & 4 & 0.859 & $\star \star \star \star ~$ & $\star \star \star \star ~$ & ** & & ns & & ns \\
\hline 47 & C/F, FLT, TME, TW & 4 & 0.867 & $\star \star \star *$ & * & $* *$ & & & ns & ns \\
\hline 48 & $\mathrm{C} / \mathrm{F}, \mathrm{PC}, \mathrm{S}, \mathrm{TME}$ & 4 & 0.827 & $\star \star \star *$ & * & & $\mathrm{ns}$ & ns & * & \\
\hline 49 & $\mathrm{C} / \mathrm{F}, \mathrm{PC}, \mathrm{S}, \mathrm{TW}$ & 4 & 0.824 & $* \star *$ & $\star \star \star *$ & & $\mathrm{~ns}$ & ns & & $\mathrm{ns}$ \\
\hline 50 & C/F, PC, TME, TW & 4 & 0.840 & $\star \star \star *$ & * & & ns & & * & ns \\
\hline 51 & $\mathrm{C} / \mathrm{F}, \mathrm{S}, \mathrm{TME}, \mathrm{TW}$ & 4 & 0.838 & $\star \star \star *$ & $\star *$ & & & ns & * & ns \\
\hline 52 & FLT, PC, S, TME & 4 & 0.837 & $\star \star \star *$ & & $* *$ & ns & ns & * & \\
\hline 53 & $\mathrm{FLT}, \mathrm{PC}, \mathrm{S}, \mathrm{TW}$ & 4 & 0.815 & $* * *$ & & * & & ns & & ns \\
\hline 54 & FLT, PC, TME, TW & 4 & 0.847 & $* * *$ & & * & ns & & ns & ns \\
\hline 55 & FLT, S, TME, TW & 4 & 0.830 & $\star \star * *$ & & * & & ns & ** & ns \\
\hline 56 & PC, S, TME, TW & 4 & 0.813 & 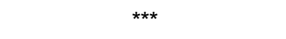 & & & ns & ns & $\star \star$ & * \\
\hline 57 & C/F, FLT, PC, S, TME & 5 & 0.874 & *** & * & ** & ns & ns & ns & \\
\hline 58 & $\mathrm{C} / \mathrm{F}, \mathrm{FLT}, \mathrm{PC}, \mathrm{S}, \mathrm{TW}$ & 5 & 0.867 & $\star \star \star *$ & ** & * & ns & ns & & ns \\
\hline 59 & $\mathrm{C} / \mathrm{F}, \mathrm{FLT}, \mathrm{PC}, \mathrm{TME}, \mathrm{TW}$ & 5 & 0.874 & $\star \star \star *$ & * & * & ns & & ns & ns \\
\hline 60 & C/F, FLT, S, TME, TW & 5 & 0.869 & $* \star *$ & * & * & & ns & ns & ns \\
\hline 61 & $\mathrm{C} / \mathrm{F}, \mathrm{PC}, \mathrm{S}, \mathrm{TME}, \mathrm{TW}$ & 5 & 0.851 & $* \star *$ & * & & $\mathrm{ns}$ & ns & * & ns \\
\hline 62 & FLT, PC, S, TME, TW & 5 & 0.848 & $\star \star \star *$ & & * & ns & ns & ns & ns \\
\hline 63 & C/F, FLT, PC, C, TME, TW & 6 & 0.877 & $* \star \star$ & ns & * & ns & ns & $\mathrm{ns}$ & ns \\
\hline
\end{tabular}

$13 \mathrm{TGY}=$ total grit yield, $\mathrm{C} / \mathrm{F}=$ coarse/fine ratio, $\mathrm{FLT}=$ floating test, $\mathrm{PC}=$ protein content, $\mathrm{S}=$ 14 sphericity, $\mathrm{TME}=$ total milling energy, $\mathrm{TW}=$ test weight. 
15 The reported $R^{2}$ refers to the average $R^{2}$ obtained from the regression analysis applied separately to samples of each dataset, clustered year by year.

17 The reported $P$ value of the regressive equation and parameters refers to the least significant 18 value observed within the 3 considered datasets; ${ }^{(*)}=$ significant at $\mathrm{P} \leq 0.05 ;^{(* *)}=$ significant at $19 \mathrm{P} \leq 0.01 ;^{(* * *)}=$ significant at $\mathrm{P} \leq 0.001$.

$20{ }^{(n s)}=$ the contribution of the parameter is not significant $(P>0.05)$ for at least one of the 21 compared databases. 
Figure. 1

24 Effect of the inclusion of parameters from different hardness tests on the coefficient of determination $\left(\mathrm{R}^{2}\right)$ of single or multiple linear regression models to predict TGY.

The reported $R^{2}$ refers to the average $R^{2}$ obtained from the single and multiple regression analysis on datasets of each year of collected and analyzed samples. Linear regressive model which did not show a significant contribution for each of the single parameter involved for all of the 3 datasets (see Tab. 3) were not considered. The number in parenthesis refers to the single and multiple linear regression models listed in Table 4.

Different letters indicate significant differences at $\mathrm{P}<0.001$ (Test SNK).

The error bars indicate the standard error of means. 
Table 5.

40 Regressive equations of the linear regression models which result in the highest

41 average $\mathrm{R}^{2}$ for the prediction of TGY.

\begin{tabular}{lll}
\hline Parameters & Regressive equation & P \\
\hline C/F, FLT (7) & TGY $=127.3 \mathrm{CF}-0.053 \mathrm{FLT}+407.7$ & $* * *$ \\
FLT, PC, TME (33) & TGY $=-0.053 \mathrm{FLT}+1.94 \mathrm{PC}+0.092 \mathrm{TME}+332.4$ & $* * *$ \\
FLT, TME (14) & TGY $=-0.058 \mathrm{FLT}+0.15 \mathrm{TME}+368.4$ & $* \star *$ \\
FLT, PC, TW (34) & TGY $=-0.054 \mathrm{FLT}+2.02 \mathrm{PC}+4.99 \mathrm{TW}-47.8$ & $* \star *$ \\
C/F, TME (10) & TGY $=133.5 \mathrm{CF}+0.13 \mathrm{TME}+102.6$ & $* * *$ \\
\hline
\end{tabular}

43 Linear regression model from hardness test across the overall dataset (119 maize kernel 44 samples, collected over 3 years)

45 The number in parenthesis for parameters refers to the models listed in Table 4.

$46 \quad\left(^{*}\right)=$ significant at $\mathrm{P} \leq 0.05 ;\left({ }^{* *}\right)$ significant at $\mathrm{P} \leq 0.01 ;\left(^{* * *}\right)$ significant at $\mathrm{P} \leq 0.001$. 